\title{
Synthesis and Antibacterial Activity of Novel Organoselenium Compounds
}

\author{
P. M. Radhakrishna (Corresponding author) \\ Provimi India Innovation Centre, Provimi Animal Nutrition India Ltd. \\ Bangalore 560 106, India \\ Tel: 91-80-2856-2298Ｅ-mail: pmradhakrishna@provimi.in
}

K. C. Sharadamma

Provimi India Innovation Centre, Provimi Animal Nutrition India Ltd.

Bangalore 560 106, India

E-mail:ksharada@provimi.in

H. M. Vagdevi

Department Of Chemistry, Sahyadri Science College (Autonomous)

Shimoga-577 203, India

E-mail: vagdevihm@gmail.com

P. M. Abhilekha

Provimi India Innovation Centre, Provimi Animal Nutrition India Ltd.

Bangalore 560 106, India

E-mail: abhilekhapmantri@provimi.in

S. Rubeena Mubeen

Provimi India Innovation Centre, Provimi Animal Nutrition India Ltd.

Bangalore 560 106, India

E-mail: rdconcept@provimi.in

\section{K. Nischal}

Provimi India Innovation Centre, Provimi Animal Nutrition India Ltd.

Bangalore 560 106, India

E-mail: knischal@provimi.in

\begin{abstract}
Organoselenium compounds are known to possess antioxidant, anticancer and antibacterial activities. In the present study, 3-[(phenylcarbonyl)selenyl]propanoic acid was synthesized and different ester derivatives of 3-[(phenylcarbonyl)selenyl]propanoic acid and 2-[(phenylcarbonyl)selenyl]acetic acid (benzoylselenoglycolic acid) were synthesized and characterized using IR, ${ }^{1} \mathrm{HNMR}$ and Mass spectral methods. Minimum Inhibitory Concentration (MIC) of the newly synthesized compounds was determined against gram positive and gram negative bacteria. Some of the compounds showed moderate to significant activity against Staphylococcus aureus, Salmonella typhimurium, Escherichia coli and Bacillus subtilis.
\end{abstract}

Keywords: Organoselenium compounds, Antibacterial activity, Esters 


\section{Introduction}

Selenium, an essential trace mineral (Rayman, 2002) is a vital component of the selenoproteins specifically glutathione peroxidase mainly required for normal health and reproduction (Rayman, 2000). Selenium was discovered in 1818 by Swedish chemist Berzelius. It was considered as a poison until it was identified as a micronutrient for bacteria, mammals and birds (Schwarz \& Foltz, 1957). Selenium is essential for the efficient and effective operation of the immune system in both animals and humans (Arthur et al,2003). Organoselenium compounds have substantially greater bioavailability than that of inorganic selenium (Cantor et al, 1975). More importantly, organic selenium is usually found to be less toxic than inorganic forms (Bendsleve et al, 1988; Khalil, 1989; Khalil, 1994).

Organoselenium compounds have been tested as antibacterial, antiviral, antifungal, antiparasitic, antihistamine and anticancer agents (Athayde-Filho et al 2004). During the last few years, tremendous effort has been directed towards the synthesis of stable organoselenium compounds that could be used as antioxidants, enzyme modulators, antitumors, antivirals, antimicrobials, antihypertensive agents and cytokine inducers (Mugesh et al, 2001; Garcia, 2004; Carland \& Fenner, 2005). Though several organoselenium compounds are known, they are less explored for their antibacterial properties. Some novel organoselenium compounds were synthesized and their antibacterial activity was tested.

One of the reagents adopted to synthesize organoselenium compounds is sodium hydrogen selenide, which can be prepared by the action of sodium borohydride on metallic selenium in protic solvents (Klayman \& Griffin, 1973). Aqueous solution of sodium hydrogen selenide has been effectively used to synthesize benzoylselenoglycolic acid (1) (Athayde-Filho et al, 2004). In the present work benzoylselenoglycolic acid was synthesized as per the reported method and 3-[(phenylcarbonyl) selenyl]propanoic acid (2) was synthesized with slight modification (Scheme 1). Several esters of compound $\mathbf{1}$ and $\mathbf{2}$ were also synthesized (Scheme 2).

\section{Experimental Section}

\subsection{Chemistry material}

Sodium borohydride, hexane, ethyl acetate were procured from RFCL India, selenium metal from Sigma Aldrich, benzoyl chloride and 3-chloropropanoic acid from Merck. Reaction was monitored using silica gel $60 \mathrm{~F}_{254} \mathrm{TLC}$ plates from Merck. Melting points were taken in open capillary tubes and are uncorrected. All the compounds were characterized by ${ }^{1} \mathrm{HNMR}$, IR, and Mass spectral methods. The IR spectra were recorded on Bruker IR spectrophotometer. ${ }^{1} \mathrm{HNMR}$ in $\mathrm{CDCl}_{3}$ was recorded on Bruker $200 \mathrm{MHz}$ instrument using TMS as internal standard and mass spectra was recorded using Shimadzu LCMS 2010A system.

\subsection{Synthesis of 3-[(Phenylcarbonyl) selenyl] propanoic acid (2)}

Selenium metal (1g, $12.66 \mathrm{mmol})$ was suspended in $12 \mathrm{~mL}$ of water. Sodium borohydride (1g, $26.5 \mathrm{mmoles})$ was dissolved in $12 \mathrm{~mL}$ of water and added slowly to the selenium suspension under nitrogen atmosphere. The reaction was exothermic with vigorous evolution of hydrogen gas. Benzoyl chloride (1.8g, $12.8 \mathrm{mmol})$ was then added slowly at $30^{\circ} \mathrm{C}$. A yellow colored solution was obtained. 3-Chloropropanoic acid (1.4g, $\left.13 \mathrm{mmol}\right) \mathrm{was}$ added slowly to the above reaction mass at $65-70^{\circ} \mathrm{C}$ and solid precipitated out towards the end of the addition. The solid was filtered and dissolved in $20 \mathrm{~mL}$ of dichloromethane and extracted into $5 \%$ sodium bicarbonate solution. The $\mathrm{pH}$ of the collected sodium bicarbonate layer was adjusted to $4-5$ using $5 \%$ hydrochloric acid. The product was extracted back into dichloromethane and concentrated under vacuum to obtain white solid. Yield: $80 \%$.

Melting point: $84-88^{0} \mathrm{C} . \quad$ IR $\left(\gamma_{\max } \mathrm{cm}^{-1}\right): 1697(-\mathrm{COOH})^{\prime} 1665(-\mathrm{Se}-\mathrm{CO}-)$.

MS: m/z: 257 (base peak) (calculated for $\mathrm{C}_{10} \mathrm{H}_{10} \mathrm{O}_{3} \mathrm{Se}: 257.14$ ).

${ }^{1} \mathrm{H}$ NMR $\left(\mathrm{CDCl}_{3}\right): \delta 2.92\left(\mathrm{t}, 2 \mathrm{H},-\mathrm{CH}_{2}-\mathrm{CO}-\right), 3.28\left(\mathrm{t}, 2 \mathrm{H},-\mathrm{Se}-\mathrm{CH}_{2}\right), 7.42-7.91(5 \mathrm{H}, \mathrm{Ar}-\mathrm{H})$.

\subsection{General procedure for the preparation of esters $(3 a-3 d)$}

Benzoylselenoglycolic acid (1) $(2.43 \mathrm{~g}, 10 \mathrm{mmol})$ was dissolved in corresponding alcoholic solvent. Thionyl chloride $(1.78 \mathrm{~g}, 15 \mathrm{mmol})$ was added slowly at $55-60^{\circ} \mathrm{C}$. Reaction mass was stirred for 30 minutes at $50-55^{\circ} \mathrm{C}$. The solvent was distilled out completely and the residue was dissolved in $15 \mathrm{~mL}$ of dichloromethane. Dichloromethane layer was washed with $10 \mathrm{~mL}$ of $5 \%$ sodium bicarbonate solution and then with water. The organic layer was collected and dried over anhydrous sodium sulfate. Solvent was distilled under vacuum and the product was obtained in the form of oil which was further purified using silica gel column. Combination of hexane and ethyl acetate was used as eluant by progressively increasing the polarity. Finally the desired compounds were eluted by hexane: ethyl acetate in the ratio of 85:15. 
Similarly ester derivatives of Compound $\mathbf{2}(\mathbf{3 e - 3 h})$ were also prepared using the same method.

2.3.1 Yield and Characterization Data

3a

Yield: $60 \%$

IR $\left(\gamma_{\max } \mathrm{cm}^{-1}\right)$ : 1720(-COO-), 1678(-Se-CO-).

MS: $\mathrm{m} / \mathrm{z}$ : 259(base peak, $[\mathrm{M}+\mathrm{H}]^{+}$) (calculated for $\mathrm{C}_{10} \mathrm{H}_{10} \mathrm{O}_{3} \mathrm{Se}:$ 257.14).

${ }^{1} \mathrm{H} \mathrm{NMR}\left(\mathrm{CDCl}_{3}\right): \delta 3.74\left(\mathrm{~s}, 3 \mathrm{H},-\mathrm{OCH}_{3}\right), 3.85\left(\mathrm{~s}, 2 \mathrm{H},-\mathrm{Se}_{-} \mathrm{CH}_{2}\right), 7.43-7.91(5 \mathrm{H}, \mathrm{Ar}-\mathrm{H})$.

3b

Yield:70\%

(IR $\left(\gamma_{\max } \mathrm{cm}^{-1}\right)$ : 1731(-COO-), 1678(-Se-CO-).

MS: m/z: 273(base peak, $[\mathrm{M}+\mathrm{H}]^{+}$) (calculated for $\mathrm{C}_{11} \mathrm{H}_{12} \mathrm{O}_{3} \mathrm{Se}:$ : 271.17).

${ }^{1} \mathrm{H}$ NMR $\left(\mathrm{CDCl}_{3}\right): \delta 1.28\left(\mathrm{t}, 3 \mathrm{H},-\mathrm{CH}_{3}\right), 3.84\left(\mathrm{~s}, 2 \mathrm{H},-\mathrm{Se}_{-} \mathrm{CH}_{2}\right), 4.19$ (quartet, $\left.2 \mathrm{H},-\mathrm{OCH}_{2}\right), 7.26-7.92(5 \mathrm{H}, \mathrm{Ar}-\mathrm{H})$.

$3 \mathrm{c}$

Yield: $70 \%$

IR $\left(\gamma_{\max } \mathrm{cm}^{-1}\right): 1725(-\mathrm{COO}-), 1677(-\mathrm{Se}-\mathrm{CO}-)$.

MS: m/z: 287(base peak, $[\mathrm{M}+\mathrm{H}]^{+}$) (calculated for $\mathrm{C}_{12} \mathrm{H}_{14} \mathrm{O}_{3} \mathrm{Se}: 285.19$ ).

${ }^{1} \mathrm{H}$ NMR $\left(\mathrm{CDCl}_{3}\right): \delta 1.24\left(\mathrm{~d}, 6 \mathrm{H},-\mathrm{C}\left(\mathrm{CH}_{3}\right)_{2}\right), 3.81\left(\mathrm{~s}, 2 \mathrm{H},-\mathrm{Se}_{-} \mathrm{CH}_{2}\right), 5.05(\mathrm{~m}, 1 \mathrm{H},-\mathrm{OCH}), 7.39-8.06(5 \mathrm{H}, \mathrm{Ar}-\mathrm{H})$.

3d

Yield:75\%

IR $\left(\gamma_{\max } \mathrm{cm}^{-1}\right)$ : 1730(-COO-), 1677(-Se-CO-).

MS: m/z: 301 (base peak, $[\mathrm{M}+\mathrm{H}]^{+}$) (calculated for $\mathrm{C}_{13} \mathrm{H}_{16} \mathrm{O}_{3} \mathrm{Se}:$ 299.22).

${ }^{1} \mathrm{H}$ NMR $\left(\mathrm{CDCl}_{3}\right): \delta$ 0.92(t, 3H, $\left.-\mathrm{CH}_{3}\right), 1.44\left(\mathrm{~m}, 2 \mathrm{H},-\mathrm{CH}_{2}\right), 1.56$ (quintet, $\left.2 \mathrm{H},-\mathrm{CH}_{2}\right), 3.84\left(\mathrm{~s}, 2 \mathrm{H},-\mathrm{Se}-\mathrm{CH}_{2}\right), 4.14(\mathrm{t}$, $\left.2 \mathrm{H},-\mathrm{OCH}_{2}\right), 7.43-7.91(5 \mathrm{H}, \mathrm{Ar}-\mathrm{H})$.

$3 e$

Yield: $75 \%$

IR $\left(\gamma_{\max } \mathrm{cm}^{-1}\right)$ : 1735(-COO-), 1668(-Se-CO-).

MS: m/z: 273 (base peak, $[\mathrm{M}+\mathrm{H}]^{+}$) (calculated for $\mathrm{C}_{11} \mathrm{H}_{12} \mathrm{O}_{3} \mathrm{Se}:$ : 271.17).

${ }^{1} \mathrm{H}$ NMR $\left(\mathrm{CDCl}_{3}\right)$ : $\delta 2.86\left(\mathrm{t}, 2 \mathrm{H},-\mathrm{CH}_{2}-\mathrm{CO}\right), 3.29\left(\mathrm{t}, 2 \mathrm{H},-\mathrm{Se}^{-\mathrm{CH}_{2}}\right), 3.71\left(\mathrm{~s}, 3 \mathrm{H},-\mathrm{OCH}_{3}\right), 7.41-7.90(5 \mathrm{H}, \mathrm{Ar}-\mathrm{H})$.

3f

Yield: $75 \%$

IR $\left(\gamma_{\max } \mathrm{cm}^{-1}\right)$ : 1731(-COO-), 1669(-Se-CO-).

MS: m/z: 287(base peak, $[\mathrm{M}+\mathrm{H}]^{+}$) (calculated for $\mathrm{C}_{12} \mathrm{H}_{14} \mathrm{O}_{3} \mathrm{Se}: 285.19$ ).

${ }^{1} \mathrm{H} \mathrm{NMR}\left(\mathrm{CDCl}_{3}\right): \delta 1.27\left(\mathrm{t}, 3 \mathrm{H},-\mathrm{CH}_{3}\right), 2.84\left(\mathrm{t}, 2 \mathrm{H},-\mathrm{CH}_{2}-\mathrm{CO}\right), 3.29\left(\mathrm{t}, 2 \mathrm{H},-\mathrm{Se}-\mathrm{CH}_{2}\right), 4.15$ (quartet, $\left.2 \mathrm{H},-\mathrm{OCH}_{2}\right)$, $7.41-7.91(5 \mathrm{H}, \mathrm{Ar}-\mathrm{H})$.

$3 \mathrm{~g}$

Yield: $85 \%$

IR $\gamma_{\max } \mathrm{cm}^{-1}:$ 1727(-COO-), 1670(-Se-CO-).

MS: m/z: 301 (base peak, $[\mathrm{M}+\mathrm{H}]^{+}$) (calculated for $\mathrm{C}_{13} \mathrm{H}_{16} \mathrm{O}_{3} \mathrm{Se}: 299.22$ ).

${ }^{1} \mathrm{H}$ NMR $\left(\mathrm{CDCl}_{3}\right): \delta 1.26\left(\mathrm{~d}, 6 \mathrm{H},-\mathrm{C}\left(\mathrm{CH}_{3}\right)_{2}\right), 2.85\left(\mathrm{t}, 2 \mathrm{H},-\mathrm{CH}_{2}-\mathrm{CO}-\right), 3.29\left(\mathrm{t}, 2 \mathrm{H},-\mathrm{Se}_{-} \mathrm{CH}_{2}\right), 5.04(\mathrm{~m}, 1 \mathrm{H},-\mathrm{OCH})$, 7.40-7.90 (5H, Ar-H).

$3 \mathbf{h}$

Yield: $87 \%$

IR $\left(\gamma_{\max } \mathrm{cm}^{-1}\right)$ : 1735(-COO-), 1673(-Se-CO-). 
MS: m/z: 315 (base peak, $[\mathrm{M}+\mathrm{H}]^{+}$) (calculated for $\mathrm{C}_{14} \mathrm{H}_{18} \mathrm{O}_{3} \mathrm{Se}: 313.25$ ).

${ }^{1} \mathrm{H}$ NMR $\left(\mathrm{CDCl}_{3}\right): \delta$ 0.94(t, 3H, $\left.-\mathrm{CH}_{3}\right), 1.39\left(\mathrm{~m}, 2 \mathrm{H},-\mathrm{CH}_{2}\right), 1.62$ (quintet, $\left.2 \mathrm{H},-\mathrm{CH}_{2}\right), 2.84\left(\mathrm{t}, 2 \mathrm{H},-\mathrm{CH}_{2}-\mathrm{CO}-\right)$, $3.29\left(\mathrm{t}, 2 \mathrm{H},-\mathrm{Se}-\mathrm{CH}_{2}\right), 4.03\left(\mathrm{t}, 2 \mathrm{H},-\mathrm{OCH}_{2}\right), 7.41-7.90(5 \mathrm{H}, \mathrm{Ar}-\mathrm{H})$.

\subsection{Antibacterial activity}

Benzoylselenoglycolic acid, 3-[(phenylcarbonyl) selenyl] propanoic acid and their esters were assayed in vitro for their antibacterial activity against a panel of selected gram positive and gram negative bacteria. They were screened for their antibacterial activity against Escherichia coli (ATCC 9637), Bacillus subtilis (ATCC 6633), Staphylococcus aureus (ATCC 29737) and Salmonella typhimurium (ATCC 23564) (recultured) bacterial strains which were obtained from National Chemical Laboratory, Pune, India.

The testing was done according to the reported method (Rose \& Miller, 1939). Samples were prepared in methanol and serially diluted to determine the minimum inhibitory concentration that inhibited the growth of the tested microorganisms (MIC). After 24 hours of incubation at $37^{\circ} \mathrm{C}$, the zone of inhibition was measured in $\mathrm{mm}$. A control was also prepared using only methanol. Doxycycline hydrochloride which is commonly used as an antibiotic in animal health industry was used as positive control. The results obtained are tabulated in Table 1.

\section{Results and Discussion}

One pot synthesis of organoselenium compounds reported in the literature for synthesizing benzoylselenoglycolic acid was used effectively to synthesize 3-[(phenylcarbonyl) selenyl] propanoic acid with slight modification in the reaction temperature. The structure of newly synthesized compound was established on the basis of spectral (IR, ${ }^{1} \mathrm{H}$ NMR, and mass) data. The IR spectrum of compound $\mathbf{2}$ showed a band in the region of $1697 \mathrm{~cm}^{-1}$ which is characteristic of carbonyl stretching of $-\mathrm{COOH}$ group and $1665 \mathrm{~cm}^{-1}$ corresponding to -Se-CO stretching. In the ${ }^{1} \mathrm{H}$ NMR spectrum the $\mathrm{Se}_{-} \mathrm{CH}_{2}$ - proton came into resonance at $\delta 3.28$ as triplet, $-\mathrm{CH}_{2}-\mathrm{CO}$ protons appeared at $\delta 2.92$ as triplet. Aromatic protons resonated between $\delta 7.42-7.91$. The signal corresponding to $-\mathrm{COOH}$ proton was not visible. However presence of $-\mathrm{COOH}$ group was confirmed through esterification reactions. The mass spectrum of this compound showed molecular ion peak at $\mathrm{m} / \mathrm{z} 257$ which is also the base peak.

Esters of compounds $\mathbf{1}$ and $\mathbf{2}$ were synthesized by the method described above and the confirmation of the structure was obtained by spectral (IR, ${ }^{1} \mathrm{H}$ NMR, and mass) methods. IR spectrum of compound $\mathbf{3 b}$ showed a band in the region of $1731 \mathrm{~cm}^{-1}$ which is characteristic of carbonyl stretching of $-\mathrm{COO}$ group. In the ${ }^{1} \mathrm{H}$ NMR spectrum the $-\mathrm{Se}-\mathrm{CH}_{2}$ - protons came into resonance at $\delta 3.84$ as singlet and $-\mathrm{OCH}_{2}$ protons resonated at $\delta 4.19$ as quartet. The $-\mathrm{CH}_{3}$ protons appeared as triplet at $\delta$ 1.28. Aromatic protons resonated between $\delta$ 7.26-7.92. The mass spectrum of this compound showed $[\mathrm{M}+\mathrm{H}]^{+}$peak at $\mathrm{m} / \mathrm{z} 273$ which is also the base peak. The mass spectra of the compounds (3b-3h) showed a common fragment peak at $\mathrm{m} / \mathrm{z} 169$. A typical pattern which is characteristic of selenium isotopic abundance (Block et al, 1996; Ip et al, 2000) was observed in the mass spectra of the compounds.

All the newly synthesized compounds were screened for their antibacterial activity. The investigation of antibacterial screening data revealed that majority of the tested compounds (1, 2 and 3a-3h) showed moderate to good inhibition against the tested bacterial species. Among all these compounds $\mathbf{3 b}$ and $\mathbf{3 d}$ showed significant inhibitory activity at lower concentrations (less than $0.1 \mathrm{mg} / \mathrm{mL}$ ) against both gram positive and gram negative bacteria except $S$. typhimurium. Compounds 3a, 3e and 3g were effective in the concentration range of 0.1-1 $\mathrm{mg} / \mathrm{mL}$ against all the bacterial species tested. Compounds $\mathbf{2}$ and $\mathbf{3 h}$ were effective against $S$. typhimurium at slightly higher concentration of $1-10 \mathrm{mg} / \mathrm{mL}$. However compounds $3 \mathbf{c}$ and $\mathbf{3 d}$ were less active against $S$. typhimurium.

\section{Conclusion}

This research study reports the successful synthesis and testing for antimicrobial activity of novel organoselenium compounds ( $\mathbf{2}$ and $\mathbf{3 a - 3 h}$ ). These compounds showed moderate to significant antibacterial activity against selected pathogenic gram positive and gram negative bacteria and these results indicate the probable role of organoselenium compounds (1-3h) against the tested pathogenic bacterial species. In conclusion, most of the target compounds exhibited in vitro antibacterial activity. Further biological evaluation of these compounds is in progress.

\section{References}

Arenholt-Bendsleve, D., Abdulla, M., Jepsrn, A., \& Pedeson, E. (1988). Effect of organic and inorganic selenium on human keratinocytes. Trace. Elem. Med, 5, 29-34. 
Arthur, J. R., McKenzie, R. C., \& Beckett, G. J. (2003). Selenium in the immune system. J. Nutr, 133, 1457S-1459S.

Athayde-Filho, P. F., Souza, A. G., Morais, S. A., Botelho, J. R., Barbosa-Filho, J. M., Miller, J., \& Lira, B. F. (2004). Synthesis and characterization of three new organo-selenium compounds. A convenient synthesis of aroylselenoglycolic acids. ARKIVOC, vi, 22-26.

Berzelius, J. J. (1818). Afhandl. Fys. Kemi Mineralog, 6, 42.

Block, E., Cai, X.-J, Uden, P. C., Zhang, X., Quimby, B. D., \& Sullivan, J. J. (1996). Allium chemistry: Natural abundance of organoselenium compounds from garlic, onion and related plants and in human garlic breath. Pure \& Appl. Chem., 68, 937-944, 1996.

Ip, C., Birringer, M., Block, E., Kotrebai, M., Tyson, J. F., Uden, P. C., \& Lisk D. J. (2000). Chemical speciation influences comparative activity of selenium-enriched garlic and yeast in mammary cancer prevention. J. Agric. Food. Chem, 48, 2062-2070.

Cantor, A. H., Langevin, M. L., Noguchi, T., \& Scott, M. L. (1975). Efficacy of selenium in selenium compounds and feedstuffs for prevention of pancreatic fibrosis in chicks. J. Nutr, 105, 96-105.

Carland, M., \& Fenner, T. (2005). The Use of Selenium-Based Drugs. In M. Gielen, \& E. R. T. Tiekink (Eds.), Medicine in metallotherapeutic drugs and metal-based diagnostic agents. Wiley, Chichester.

Khalil, A. M. (1989). The induction of chromosome aberrations in human purified peripheral blood lymphocytes following in vitro exposure to selenium. Mutat. Res, 224, 503-506.

Khalil, A. M. (1994). Genotoxicity of two pharmacologically important selenium compounds (selenocystine and selenopuridine) in cultured human blood lymphocytes. Toxicol. Environ. Chem, 41, 147-154.

Klayman, D. L., \& Griffin, T. S. (1973). Reaction of selenium with sodium borohydride in protic solvents. A facile method for introduction of selenium into organic molecules. J. Am. Chem. Soc, 95, 197-199.

Mugesh, G., du Mont, W. W., and Sies, H. (2001). Chemistry of biologically important synthetic organoselenium compounds. Chem. Rev, 101, 2125-2179.

Rayman, M. P. (2000). The importance of selenium to human health. Lancet, 356, 233-241.

Rayman, M. P. (2002). The argument for increasing selenium intake. Proc. Nutr. Soc, 61, 203-215.

Rose, S. B., \& Miller, R. E. (1939). Studies with the agar cup-plate method. I. A standardized agar cup-plate technique. J. Bacteriol, 38, 525-537.

Schwarz, K., \& Foltz, C. M. (1957). Selenium as an integral part of factor 3 against dietary necrotic liver degeneration. J. Am. Chem. Soc, 79, 3292-3293.

Soriano-Garcia, M. (2004). Organoselenium compounds as potential therapeutic and chemopreventive agents: A review. Curr. Med. Chem, 11, 1657-1669.

Table 1. Antibacterial activities of compounds $\mathbf{1}, \mathbf{2}, \mathbf{3 a}-\mathbf{3 h}$

\begin{tabular}{|c|c|c|c|c|}
\hline Compound & S. aureus & E. coli & S. typhimurium & B. subtilis \\
\hline 1 & +++++ & ++++ & +++ & +++++ \\
\hline 2 & +++++ & +++++ & ++++ & +++++ \\
\hline $3 \mathrm{a}$ & +++++ & ++++++ & +++++ & +++++ \\
\hline $3 \mathrm{~b}$ & ++++++ & ++++++ & +++++ & ++++++ \\
\hline $3 \mathrm{c}$ & +++++ & ++++++ & ++ & +++++ \\
\hline $3 \mathrm{~d}$ & ++++++ & ++++++ & + & ++++++ \\
\hline $3 \mathrm{e}$ & +++++ & +++++ & +++++ & +++++ \\
\hline $3 \mathrm{~g}$ & ++++ & ++++ & +++ & ++++ \\
\hline $3 \mathrm{~h}$ & +++++ & +++++ & +++++ & +++++ \\
\hline $\begin{array}{c}\text { Doxycyline } \\
\text { Hydrochloride }\end{array}$ & +++++ & +++++ & ++++ & +++++ \\
\hline
\end{tabular}

Less than $0.1 \mathrm{mg} / \mathrm{mL}=++++++, 0.11-1 \mathrm{mg} / \mathrm{mL}=+++++, 1-10 \mathrm{mg} / \mathrm{mL}=++++, 10.1-50 \mathrm{mg} / \mathrm{mL}=+++$,

$51-100 \mathrm{mg} / \mathrm{mL}=++$, above $100 \mathrm{mg} / \mathrm{mL}=+$. 


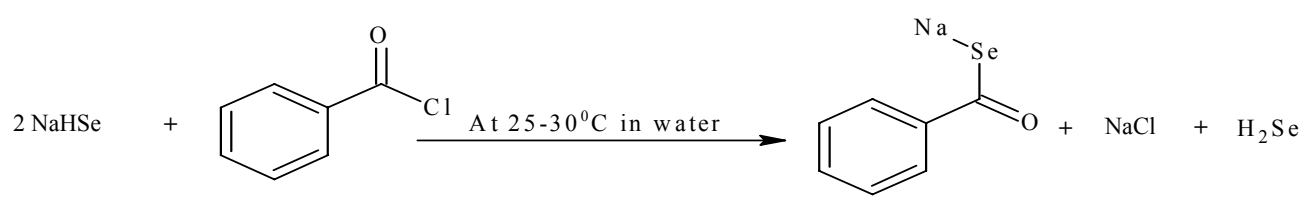<smiles>NNC(=O)c1ccccc1</smiles>

Scheme 1. Synthesis of compounds 1 and 2<smiles>O=C(O)CNC(=O)c1ccccc1</smiles>

$1 \mathrm{n}=1$

$2 \mathrm{n}=2$

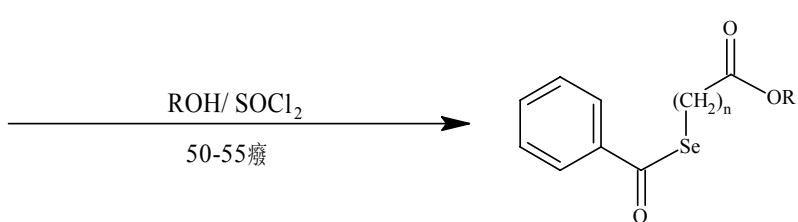

3(a-h)

3a $\mathrm{R}=\mathrm{CH}_{3}(\mathrm{n}=1), 3 \mathrm{~b} \mathrm{R}=\mathrm{C}_{2} \mathrm{H}_{5}(\mathrm{n}=1), 3 \mathrm{c} \mathrm{R}=\mathrm{CH}\left(\mathrm{CH}_{3}\right)_{2}(\mathrm{n}=1)$ and $3 \mathrm{~d} \mathrm{R}=\mathrm{CH}_{2}-\mathrm{CH}_{2}-\mathrm{CH}_{2}-\mathrm{CH}_{3}(\mathrm{n}=1)$ $3 e \mathrm{R}=\mathrm{CH}_{3}(\mathrm{n}=2), 3 \mathrm{f} \mathrm{R}=\mathrm{C}_{2} \mathrm{H}_{5}(\mathrm{n}=2), 3 \mathrm{~g} \mathrm{R}=\mathrm{CH}\left(\mathrm{CH}_{3}\right)_{2}(\mathrm{n}=2)$ and $3 \mathrm{~h} \mathrm{R}=\mathrm{CH}_{2}-\mathrm{CH}_{2}-\mathrm{CH}_{2}-\mathrm{CH}_{3}(\mathrm{n}=2)$

Scheme 2. Synthesis of esters $3 a-3 h$ 